\title{
A Two-Step Bioconversion Process for Canolol Production from Rapeseed Meal Combining an Aspergillus niger Feruloyl Esterase and the Fungus Neolentinus lepideus
}

\author{
Elise Odinot ${ }^{1}$, Frédéric Fine ${ }^{2}$, Jean-Claude Sigoillot ${ }^{1}$, David Navarro ${ }^{1,3}$, Oscar Laguna ${ }^{4}$, \\ Alexandra Bisotto ${ }^{1}$, Corinne Peyronnet ${ }^{5}$, Christian Ginies ${ }^{6}$ (D), Jérôme Lecomte ${ }^{4}$, \\ Craig B. Faulds ${ }^{1}$ and Anne Lomascolo ${ }^{1, *}$ \\ 1 INRA Institut National de la Recherche Agronomique, Aix Marseille Univ., UMR1163 BBF Biodiversité \\ et Biotechnologie Fongiques, 163 Avenue de Luminy, 13288 Marseille CEDEX 09, France; \\ elise.odinot@univ-amu.fr (E.O.); jean-claude.sigoillot@univ-amu.fr (J.-C.S.); \\ david.navarro@univ-amu.fr (D.N.); alexandra.bisotto@univ-amu.fr (A.B.); craig.faulds@univ-amu.fr (C.B.F.) \\ 2 Terres Inovia, Parc Industriel, 11 Rue Monge, 33600 Pessac, France; f.fine@terresinovia.fr \\ 3 Centre International de Ressources Microbiennes, Champignons Filamenteux, CIRM-CF, Case 925, \\ 163 Avenue de Luminy, 13288 Marseille CEDEX 09, France \\ 4 CIRAD Centre de coopération Internationale en Recherche Agronomique pour le Développement, \\ UMR IATE Montpellier SupAgro-INRA, 2, Place Pierre Viala, 34060 Montpellier, France; \\ oscar.laguna@cirad.fr (O.L.); jerome.lecomte@cirad.fr (J.L.) \\ 5 Terres Univia, 11 rue Monceau, CS60003, 75378 Paris CEDEX 8, France; c.peyronnet@terresunivia.fr \\ 6 Sécurité et Qualité des Produits d'Origine Végétale, INRA Institut National de la Recherche Agronomique \\ UMR408 SQPOV, Université d'Avignon, 33 rue Louis Pasteur, 84029 Avignon, France; \\ christian.ginies@inra.fr \\ * Correspondence: anne.lomascolo@univ-amu.fr; Tel.: +33-4-91-82-86-06
}

Received: 5 September 2017; Accepted: 11 October 2017; Published: 14 October 2017

\begin{abstract}
Rapeseed meal is a cheap and abundant raw material, particularly rich in phenolic compounds of biotechnological interest. In this study, we developed a two-step bioconversion process of naturally occurring sinapic acid (4-hydroxy-3,5-dimethoxycinnamic acid) from rapeseed meal into canolol by combining the complementary potentialities of two filamentous fungi, the micromycete Aspergillus niger and the basidiomycete Neolentinus lepideus. Canolol could display numerous industrial applications because of its high antioxidant, antimutagenic and anticarcinogenic properties. In the first step of the process, the use of the enzyme feruloyl esterase type-A (named AnFaeA) produced with the recombinant strain A. niger BRFM451 made it possible to release free sinapic acid from the raw meal by hydrolysing the conjugated forms of sinapic acid in the meal (mainly sinapine and glucopyranosyl sinapate). An amount of 39 nkat AnFaeA per gram of raw meal, at $55^{\circ} \mathrm{C}$ and $\mathrm{pH} 5$, led to the recovery of 6.6 to $7.4 \mathrm{mg}$ of free sinapic acid per gram raw meal, which corresponded to a global hydrolysis yield of 68 to $76 \%$ and a $100 \%$ hydrolysis of sinapine. Then, the XAD2 adsorbent (a styrene and divinylbenzene copolymer resin), used at $\mathrm{pH} 4$, enabled the efficient recovery of the released sinapic acid, and its concentration after elution with ethanol. In the second step, 3-day-old submerged cultures of the strain N. lepideus BRFM15 were supplied with the recovered sinapic acid as the substrate of bioconversion into canolol by a non-oxidative decarboxylation pathway. Canolol production reached $1.3 \mathrm{~g} / \mathrm{L}$ with a molar yield of bioconversion of $80 \%$ and a productivity of $100 \mathrm{mg} / \mathrm{L}$ day. The same XAD2 resin, when used at $\mathrm{pH} \mathrm{7,} \mathrm{allowed} \mathrm{the} \mathrm{recovery} \mathrm{and} \mathrm{purification} \mathrm{of}$ canolol from the culture broth of $N$. lepideus. The two-step process used mild conditions compatible with green chemistry.
\end{abstract}

Keywords: Aspergillus niger; canolol; feruloyl esterase; Neolentinus lepideus; rapeseed meal; sinapic acid 


\section{Introduction}

Rapeseed is one of the most widely grown oil crops in the world, both in terms of quantities and surface areas, to produce oils for the food or energy (biofuel) industries. Rapeseed meals (RSM), which are the solid by-products of oil extraction processes from seeds, consist mainly of proteins, fibers (pectins, cellulose, hemicelluloses) and minerals [1]. By 2016, the global production of RSM was around 39 million tons [2]. Due to these tonnages, the use and the valorization of these meals became indispensable for a sustainable bio-economy and have been the object of various studies over recent decades. For many years, RSM in the case of digestible varieties have been used mainly as a source of protein hydrolysates for animal feed. In the case of non-digestible cultivars (containing antinutritional factors such as glucosinolates, phytates, polyphenols or erucic acid), RSM were burnt or used as soil fertilizer.

More recently, new alternatives to the traditional use of agri-food by-products for animal feed have emerged, especially for the production of value-added compounds of biotechnological and industrial interest (for a review, see [1]). For instance, meals could be thermo-chemically transformed into natural composite and plastic materials or synthetic additives [3]. Otherwise, RSM proved to be very good physical substrate of microbial growth (porous fibrous structure, adequate chemical composition as source of carbon and nitrogen, minerals and vitamins), as well as being cheap and available in large quantities. In the literature, there are some examples of microbial biotransformations from meals for the production of high value-added molecules, including enzymes, antibiotics, antioxidants, vitamins, lipids, biogas or bioethanol [4-9].

Rapeseed meal is particularly rich in phenolic compounds which account for 5 to $18 \mathrm{~g} / \mathrm{kg}[10,11]$. The major phenolic compound is sinapic acid (4-hydroxy-3,5-dimethoxycinnamic acid), which is essentially found in esterified forms (Figure 1). The esters of sinapic acid (SA), mainly sinapine (sinapoyl choline) and glucopyranosyl sinapate, represent $90-95 \%$ of all the phenolics while the amount of SA in the free form does not exceed 0.03-0.04\% [11].

Canolol (2,6-dimethoxy-4-vinylphenol or vinylsyringol) is one of the high value-added molecules that can be obtained from RSM. Discovered and characterized a dozen years ago [12,13], it is the product of SA decarboxylation (Figure 1) which occurrs during the process of oil extraction at high temperature. The canolol content is about $1 \mathrm{mg} / \mathrm{g}$ in unrefined crude oils (olive, rapeseed, sesame) but it disappears completely at the end of the refining stages. Canolol is the phenolic compound mostly responsible for the increased oxidative stability of the crude rapeseed oil after the roasting treatment. It has an antioxidant activity comparable to $\gamma$-tocopherol, and higher than other natural known antioxidants such as $\alpha$-tocopherol, vitamin $C$ or $\beta$-carotene $[12,13]$. Moreover, canolol is lipophilic, and shows a better affinity with cell membranes than hydrophilic antioxidants. For instance, canolol was shown to inhibit the intracellular production of free radicals in mammalian cells and to prevent DNA cleavage by these free radicals naturally produced during cell inflammation [14]. Antioxidant and anti-inflammatory effects of canolol have been demonstrated in retinal cell lines [15], and would also play a protective role in cases of inflammation caused by Helicobacter pylori gastritis [16]. Canolol specifically reduced the expression level of the gene encoding cyclooxygenase COX-2, a marker of inflammatory activity strongly expressed in tumors where it contributes to inactivate apoptosis. All of these properties seem to confer on canolol a prevention activity against various cancers [17]. In addition, canolol could be the precursor of: (i) natural bio-based monomers (diepoxydized diphenyls) that could advantageously replace the diglycidyl ether of bisphenol A; and (ii) thermoplastic biopolymers $[18,19]$.

It is possible to obtain the decarboxylation of SA into canolol by classical heat treatment $\left(165^{\circ} \mathrm{C}\right)$ of RSM, with yields between 500 and $800 \mathrm{mg} / \mathrm{kg}$, by microwave [20-22], or by combining heat, pressure and solvent extraction with alkali [23]. However, the conversion yields remain very low and processes fairly random to scaling-up. Non-oxidative microbial decarboxylation of phenolic compounds to vinyl derivatives has been described historically for ferulic acid (4-hydroxy-3-methoxycinnamic acid) in the residues of fermented products including beer and whisky [24]. This microbial activity involves an intracellular enzyme called phenolic acid decarboxylase (PAD), described in bacilli bacteria and 
some yeasts till now [25-27]. The substrate specificity of the native microbial PADs was described only for ferulic, $p$-coumaric and caffeic acids, in the decreasing order. Recently, a process of SA bioconversion into canolol has been developed with a mutated PAD from Bacillus pumilus, in a biphasic (water/toluene) system ensuring continuous extraction and recovery of canolol in the organic phase. The yield was about $3 \mathrm{mg} / \mathrm{g}$ meal but SA was obtained by alkaline hydrolysis of the meal followed by two successive extraction steps with hexane, diethyl ether and ethyl acetate [11].

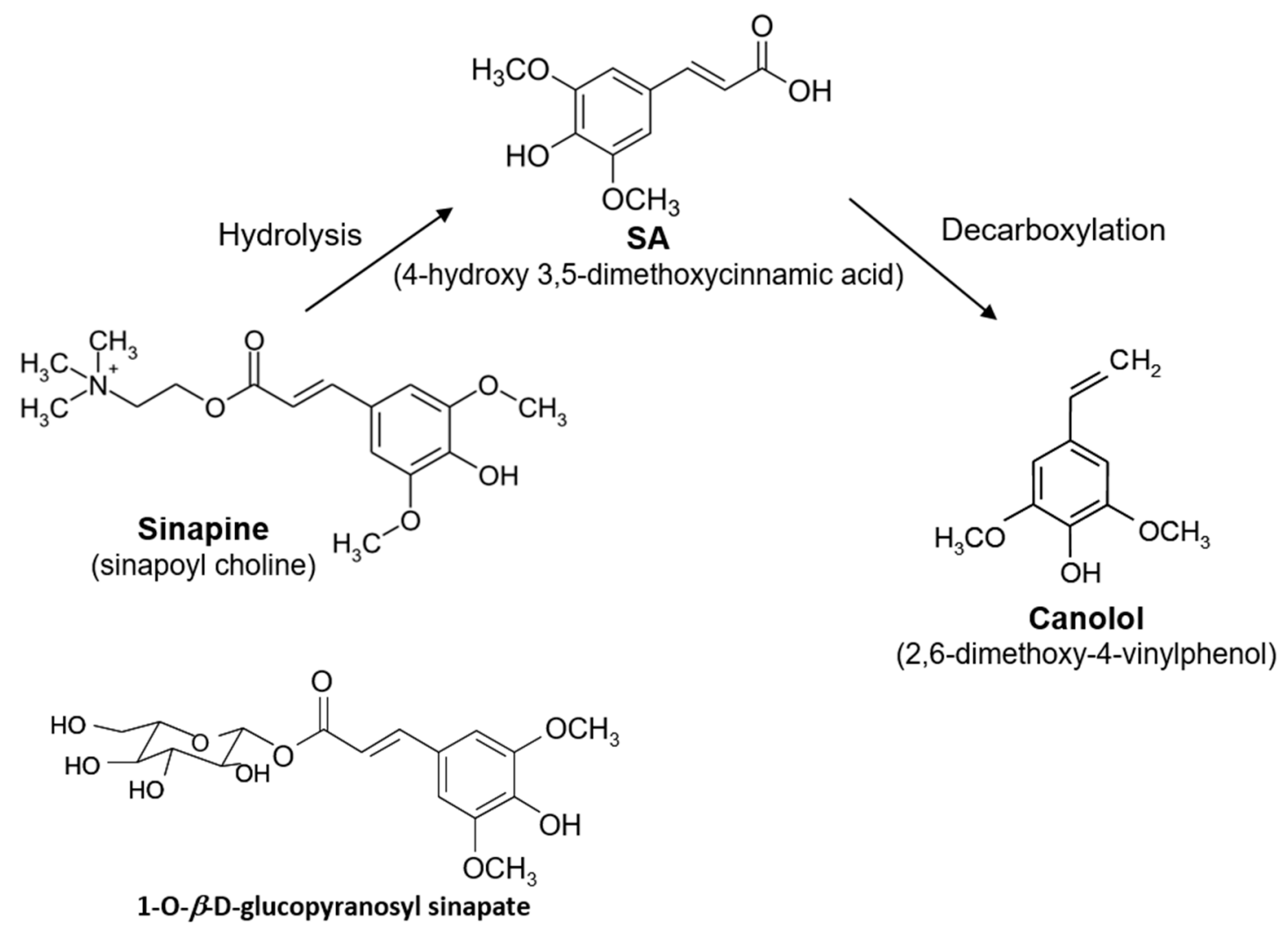

Figure 1. Canolol synthesis from the main esterified forms of SA from rapeseed meal.

The objective of our work was to develop an alternative strategy based on a two-step bioconversion process to produce up to $1-1.5 \mathrm{~g} / \mathrm{L}$ canolol from RSM in fungal cultures under mild conditions compatible with green chemistry. In the first step, an Aspergillus niger type-A recombinant feruloyl esterase (AnFaeA) enabled the release of free SA from its esterified forms present in the raw meal with a global hydrolysis yield of 68 to $76 \%$. In the second step, 3-day-old submerged cultures of the strain N. lepideus BRFM15 were supplied with the recovered sinapic acid as the substrate of bioconversion into canolol by a non-oxidative decarboxylation pathway. Canolol production reached $1.277 \mathrm{~g} / \mathrm{L}$ with a molar yield of bioconversion of $80 \%$ and a productivity of $100 \mathrm{mg} / \mathrm{L}$-day.

\section{Materials and Methods}

\subsection{Plant Material}

Rapeseed meal was provided by the Technical Centre for Oilseed Crops, Grain Legumes and Industrial Hemp (TERRES INOVIA, Pessac, France). It was obtained after oil extraction from rapeseeds at $107 \pm 2{ }^{\circ} \mathrm{C}$ for $80 \pm 5 \mathrm{~min}$. 


\subsection{Chemicals}

All the chemicals were purchased from Sigma-Aldrich (Saint-Quentin Fallavier, France), except syringyl alcohol and protocatechuic alcohol (Alfa Aesar, Schiltigheim, France) and sinapine thiocyanate (Wilshire Technologies Inc., Princeton, NJ, USA). Pure canolol was kindly provided by the Laboratory of Agro-polymers and Emerging Technologies of the French National Institute for Agricultural Research (CIRAD-UMR IATE, Montpellier, France). The molecular masses of canolol, SA, sinapine and sinapine thiocyanate were of 180.2, 224.21, 310.37 and $368.45 \mathrm{~g} / \mathrm{mol}$, respectively.

\subsection{Microorganisms and Culture Conditions}

The strains Neolentinus lepideus BRFM15, Schizophyllum commune BRFM823 (deposited by the Université Joseph Fourier, Grenoble, France, as CMPG1552), Stereum hirsutum BRFM889, Aspergillus niger BRFM281, A. niger BRFM451, A. niger BRFM766 and A. niger BRFM891 were obtained from the CIRM-CF collection (International Centre of Microbial Resources dedicated to Filamentous Fungi, INRA, Marseille, France). The strains were kept on malt agar slants at $4{ }^{\circ} \mathrm{C}$.

For hydroxycinnamic acid bioconversion assays, N. lepideus BRFM15, Schizophyllum commune BRFM823, and Stereum hirsutum BRFM889 were grown in Roux flasks on the following preculture medium: glucose $(10 \mathrm{~g} / \mathrm{L})$, yeast extract $(1 \mathrm{~g} / \mathrm{L})$ and bactopeptone $(2 \mathrm{~g} / \mathrm{L})$. After incubation at $30^{\circ} \mathrm{C}$ for 10 days, mycelium from three flasks was collected, mixed with $50 \mathrm{~mL}$ sterile water and blended $1 \mathrm{~min}$ at 9000 rpm with an Ultra-Turrax T-25 (Janke \& Kunkel, GMBM \& Co., KG, Staufen, Germany). Mycelial inoculum corresponded to $0.5-0.6 \mathrm{~g}$ mycelium dry weight per liter of culture medium. Cultures were grown at $30{ }^{\circ} \mathrm{C}$ and $120 \mathrm{rpm}$ in 250-mL Erlenmeyer baffled flasks containing $100 \mathrm{~mL}$ culture medium: glucose $(20 \mathrm{~g} / \mathrm{L})$, yeast extract $(0.5 \mathrm{~g} / \mathrm{L}),\left(\mathrm{NH}_{4}\right)_{2} \mathrm{C}_{4} \mathrm{H}_{4} \mathrm{O}_{6}(1.84 \mathrm{~g} / \mathrm{L}), \mathrm{KH}_{2} \mathrm{PO}_{4}(0.2 \mathrm{~g} / \mathrm{L}), \mathrm{CaCl}_{2} \cdot 2 \mathrm{H}_{2} \mathrm{O}$ $(0.00132 \mathrm{~g} / \mathrm{L}), \mathrm{MgSO}_{4} \cdot 7 \mathrm{H}_{2} \mathrm{O}(0.5 \mathrm{~g} / \mathrm{L})$, and thiamine chlorhydrate $(0.0025 \mathrm{~g} / \mathrm{L})$. After three days of incubation, the hydroxycinnamic acid (either SA, or ferulic, or caffeic, or $p$-coumaric acid) was added as a filter-sterilized solution at a final concentration of $0.3 \mathrm{~g} / \mathrm{L}$. Phenolic precursor feeding was performed daily in order to maintain $0.3 \mathrm{~g} / \mathrm{L}$ as the final concentration in the culture medium.

The strain A. niger BRFM281 was grown on the same culture medium, depleted in thiamine chlorhydrate, and with $2.5 \mathrm{~g} / \mathrm{L}$ maltose instead of $20 \mathrm{~g} / \mathrm{L}$ glucose. The medium was supplemented with $15 \mathrm{~g} / \mathrm{L}$ RSM. Cultures were inoculated with $2 \times 10^{5}$ conidiospores per $\mathrm{mL}$. Incubation was carried at $30{ }^{\circ} \mathrm{C}$ in 500-mL Erlenmeyer baffled flasks containing $100 \mathrm{~mL}$ medium.

The recombinant strains A. niger BRFM451, A. niger BRFM766 and A. niger BRFM891 were, respectively, feruloyl esterase A (AnFaeA), feruloyl esterase B (AnFaeB) and chlorogenate esterase (ChlE) overproducing strains, formerly obtained, in our laboratory, by genetic engineering of the host strain A. niger D15\#26, as previously described [28-30]. In this study, these strains were respectively used to produced batches of AnFaeA, AnFaeB and ChlE, in a culture medium containing: glucose $(50 \mathrm{~g} / \mathrm{L}), \mathrm{NaNO}_{3}(5.95 \mathrm{~g} / \mathrm{L}), \mathrm{KCl}(0.52 \mathrm{~g} / \mathrm{L}), \mathrm{MgSO}_{4} \cdot 7 \mathrm{H}_{2} \mathrm{O}(0.49 \mathrm{~g} / \mathrm{L})$, trace elements $(1000 \times$ stock: $\mathrm{ZnSO}_{4} \cdot 7 \mathrm{H}_{2} \mathrm{O} 21.85 \mathrm{~g} / \mathrm{L}, \mathrm{H}_{3} \mathrm{BO}_{3} 11 \mathrm{~g} / \mathrm{L}, \mathrm{MnCl}_{2} \cdot 4 \mathrm{H}_{2} \mathrm{O} 4.95 \mathrm{~g} / \mathrm{L}, \mathrm{FeSO}_{4} \cdot 7 \mathrm{H}_{2} \mathrm{O} 5 \mathrm{~g} / \mathrm{L}, \mathrm{CoCl}_{2} \cdot 6 \mathrm{H}_{2} \mathrm{O}$ $1.69 \mathrm{~g} / \mathrm{L}, \mathrm{CuSO}_{4} \cdot 5 \mathrm{H}_{2} \mathrm{O} 1.6 \mathrm{~g} / \mathrm{L}, \mathrm{Na}_{2} \mathrm{MoO}_{4} \cdot 2 \mathrm{H}_{2} \mathrm{O} 1.5 \mathrm{~g} / \mathrm{L}$, EDTA-Na2 $2 \cdot 2 \mathrm{H}_{2} \mathrm{O} 64.76 \mathrm{~g} / \mathrm{L}$ ) in a $0.1 \mathrm{M}$ citrate-sodium phosphate buffer at $\mathrm{pH} 5$ [29].

\subsection{Accession Numbers of Protein Sequences}

The accession numbers of the protein sequences of the fungal PADs predicted from the genome of the strains N. lepideus HHB14362, S. commune H4-8 and S. hirsutum FP-91666 were, respectively, in the NCBI database: KZT30061.1, XP_003032860.1, and XP_007303961.1 [31]. The accession numbers of the protein sequences of AnFaeA, AnFaeB and ChlE were, respectively, in the NCBI database: CAA70510, AJ309807, and ABK62698. 


\subsection{Enzyme Activity Assay}

Esterase activity was assayed spectrophotometrically at $37^{\circ} \mathrm{C}$, as previously described [32], by monitoring the $\mathrm{A}_{335}$ with respect to the rate of hydrolysis of $0.032 \mathrm{mmol} / \mathrm{L}$ of the enzyme substrate in $88 \mathrm{mmol} / \mathrm{L}$ of a 3-( $\mathrm{N}$-morpholino)propanesulfonic acid (MOPS) buffer (pH 5.5). The substrates used were respectively methyl sinapate and methyl ferulate for AnFaeA, methyl caffeate and methyl $p$-coumarate for AnFaeB, and chlorogenic acid for ChlE. The extinction coefficients at $335 \mathrm{~nm}$ were $13,318,5500,19,524,4409,12,560,6060,821,673$, and 15,423 L/(mol $\cdot \mathrm{cm})$ for methyl sinapate, sinapic acid, methyl ferulate, ferulic acid, methyl caffeate, caffeic acid, methyl $p$-coumarate, $p$-coumaric acid, and chlorogenic acid, respectively. Enzyme activity was expressed in nanokatal. One nanokatal of activity is defined as the quantity of enzyme which hydrolyzed $1 \mathrm{nmol}$ of substrate per second. The experiments were performed in triplicate and the standard deviation was lower than $5 \%$ of the mean.

\subsection{Screening of Resins for Aromatic Compound Adsorption}

Four resins were used: one polystyrenic resin Amberlite ${ }^{\circledR}$ XAD16, two styrene and divinylbenzene copolymer resins, respectively Sepabeads ${ }^{\circledR}$ SP207 and Amberlite ${ }^{\circledR}$ XAD2, and one styrene divinylbenzene polyaromatic copolymer resin Amberlite ${ }^{\circledR}$ XAD1180N, all purchased from Sigma-Aldrich (Saint-Quentin Fallavier, France). Before use, adsorbents were washed with water and ethanol. The affinity of SA and canolol for these resins was determined in 50-mL solutions containing $5 \mathrm{~g}$ wet resin, $178 \mathrm{mg} / \mathrm{L} \mathrm{SA}$ and $380 \mathrm{mg} / \mathrm{L}$ canolol. After an overnight incubation at $30^{\circ} \mathrm{C}$ and $120 \mathrm{rpm}$, the mix was filtered on glass-fibre G1 filters. The resulting filtrate was recovered and then the resin was washed with $50 \mathrm{~mL}$ of water and eluted two times with pure ethanol (50 than $20 \mathrm{~mL}$ ) at $30{ }^{\circ} \mathrm{C}$ and $120 \mathrm{rpm}$ for $1.5 \mathrm{~h}$. The aqueous and ethanolic eluates were immediately analyzed by HPLC as described below. The adsorption ratio of each compound for the resin was calculated as follows:

$$
\text { adsorption ratio }(\%)=\frac{\left(C_{0}-C^{*}\right) \times 100}{C_{0}}
$$

$C_{0}$ initial concentration of sinapic acid or canolol (mmol/L)

$\mathrm{C}^{*}$ equilibrium concentration of sinapic acid or canolol ( $\left.\mathrm{mmol} / \mathrm{L}\right)$

\subsection{Enzymatic Hydrolysis of Rapeseed Meal}

For the enzymatic hydrolysis assays, batches of recombinant AnFaeA, AnFaeB and ChlE were used. One hundred milliliters of $100 \mathrm{mM}$ MOPS (3-( $N$-morpholino)propanesulfonic acid) buffer (pH 5.5), containing $5 \mathrm{~g}$ RSM was incubated for $1 \mathrm{~h}$ at $30^{\circ} \mathrm{C}$ and $150 \mathrm{rpm}$ for homogenization and then either 30.5 nkat AnFaeA or 18.2 nkat ChlE or 26.1 nkat AnFaeB was added. The enzymatic hydrolysis assay was then run at $37^{\circ} \mathrm{C}$ and $150 \mathrm{rpm}$ for 1 to $4 \mathrm{~h}$. The reference reaction mixture was performed in the same conditions but in the absence of any enzyme. The release of sinapine and SA from RSM was followed by HPLC analysis of the buffer mixture, according to the method described below.

\subsection{Batch Production of Sinapic Acid from Rapeseed Meal}

Four hundred and ten grams of RSM (dry weight) were incubated with 17,640 nkat AnFaeA (i.e., 39 nkat AnFaeA per gram of meal) and $8 \mathrm{~L}$ of $100 \mathrm{mM}$ MOPS buffer (pH 5), with an agitation of $500 \mathrm{rpm}$ in a 10-L Pierre Guérin Tryton bioreactor of standard geometry (Pierre Guérin technologies, Mauze, France), for $3.5 \mathrm{~h}$ at $55^{\circ} \mathrm{C}$. The mechanically agitated tank was equipped with a pitch blade impeller ( $6.5 \mathrm{~cm}$ in diameter) and a VMI centripetal impeller $(5.5 \mathrm{~cm}$ in diameter, VMI Rayneri, Montaigu, France) separated each other by $11.8 \mathrm{~cm}$. The residual meal was then removed by filtration and the $\mathrm{pH}$ of the resulting supernatant was adjusted to $\mathrm{pH} 4$ with $\mathrm{HCl}$ before an overnight incubation with $500 \mathrm{~g}$ resin XAD2, at $30^{\circ} \mathrm{C}$ and $160 \mathrm{rpm}$, in order to specifically adsorb SA. The elution of SA 
from the resin was performed with $2 \mathrm{~L}$ ethanol. Ethanol was further evaporated under vacuum at $30{ }^{\circ} \mathrm{C}$ to obtain a concentrated SA solution of $25 \mathrm{~g} / \mathrm{L}$.

\subsection{Characterization of Rapeseed Meal}

Dry matter content of rapeseed meal (RSM) was determined by drying at $110{ }^{\circ} \mathrm{C}$ until constant mass was obtained.

Lipid content of RSM was determined by hexane extraction using a ratio of $10 \%(w / v)$ meal in solvent. Extraction was carried out by stirring the substrate in the solvent for 3 days at room temperature. After filtration on a G2 fritted glass filter, hexane was evaporated to dryness and the lipid residue was weighed.

For the determination of total phenolic content of meal, $0.5 \mathrm{~g}$ RSM and $50 \mathrm{~mL}$ of $70 \%(v / v)$ aqueous ethanol were incubated at $75{ }^{\circ} \mathrm{C}$ for $1 \mathrm{~h}$ under continuous stirring. The clear phenolic extract was collected after centrifugation (4000 rpm, 20 min, Fiberlite ${ }^{\circledR}$ F15S-6x100y rotor, Sorvall ST40 centrifuge, Thermoscientific, Illkirch, France) to discard proteins. The total phenolic content was determined colorimetrically at $750 \mathrm{~nm}$ by the Folin-Ciocalteu reagent, using SA as calibration standard. Results of analyses were expressed as $\mathrm{mg} / \mathrm{L}$ or $\mathrm{mg} / \mathrm{g}$ dry matter of SA equivalents (SAE). The calibration curve was established from 0 to $100 \mathrm{mg} / \mathrm{L}$.

The total amount of sinapine and free SA present in the raw meal was determined as follows: $50 \mathrm{mg}$ RSM was added to $5 \mathrm{~mL}$ methanol and incubated at $75{ }^{\circ} \mathrm{C}$ for $20 \mathrm{~min}$ under stirring. After centrifugation $(3000 \times g, 5 \mathrm{~min})$, the organic phase was analyzed by HPLC to calculate the amount of sinapine and free SA. The total amount of SA, initially present in the raw RSM as various esterified forms and potentially releasable, was determined after alkaline hydrolysis. Fifty milligrams of RSM were diluted with $1.5 \mathrm{~mL}$ of methanol. Then, $6 \mathrm{~mL}$ of $\mathrm{NaOH} 2 \mathrm{~N}$ were added to the mixture for incubation at $30{ }^{\circ} \mathrm{C}$ for $30 \mathrm{~min}$. At the end of the incubation, the mixture was acidified at $\mathrm{pH} 2$ using $4 \mathrm{~N} \mathrm{HCl}$ and $300 \mathrm{mg} \mathrm{NaCl}$. Samples were extracted three times with ethyl acetate $(2 \mathrm{~mL})$ by vortexing for $2 \mathrm{~min}$. After each extraction, the samples were centrifuged $(3000 \times g, 5 \mathrm{~min})$ and the supernatants collected. The organic phases were pooled and dried under nitrogen flow. The residue was dissolved in a final volume of $0.5 \mathrm{~mL}$ methanol/water $(2: 1, v / v)$ prior to HPLC analysis for total SA quantification. HPLC analysis was performed at $30^{\circ} \mathrm{C}$ on a model XR UFL Shimadzu LC-20AD equipped with a SPD-M20A variable UV detector (Kyoto, Japan). Separations were achieved on a C18 reversed-phase column (C18 121-2546 $5 \mu \mathrm{m}, 4.6 \times 250$ mm, Phénomenex, Le Pecq, France). The flow rate was $1 \mathrm{~mL} / \mathrm{min}$. The used mobile phases were solvent $\mathrm{A}$ : water acidified by $0.1 \%$ acetic acid $(v / v)$, and solvent B: methanol acidified by $0.1 \%$ acetic acid $(v / v)$. The gradient changed as follows: solvent $B$ started at $15 \%$ for $5 \mathrm{~min}$, increased to $80 \%$ in $25 \mathrm{~min}$, then to $100 \%$ in $1 \mathrm{~min}$ until the end of running (35 min). The quantification of compounds was performed by external standard calibration at 323 and $328 \mathrm{~nm}$ for SA and sinapine, respectively, using commercial SA and sinapine thiocyanate.

\subsection{Extraction, Derivatization and Gas Chromatography-Mass Spectrometry (GC-MS) of the Monomeric Phenolics from N. lepideus Culture Broth}

Clarified supernatants of $\mathrm{N}$. lepideus BRFM15 cultures were adjusted to $\mathrm{pH} 3$ with $\mathrm{HCl}$ and twice extracted with ethyl acetate $(1: 1, v / v)$. The pooled ethyl acetate phase was evaporated to dryness and the residue dissolved in $2 \mathrm{~mL}$ of ethyl acetate for subsequent analyses. One $\mathrm{mL}$ was then completely dried and submitted to the following procedure for derivatization prior to GC-MS analysis: $297 \mu \mathrm{L}$ of $N$-methyl- $N$-(trimethylsilyl)fluoroacetamide (MSTFA) and $3 \mu \mathrm{L}$ of $2 \%$ $(w / v)$ methoxyamine hydrochloride in pyridine were incubated with the sample for $15 \mathrm{~min}$ at $60^{\circ} \mathrm{C}$. Trimethylsilyl derivatives of monomeric phenolic extracts were then analyzed by GC-MS using an Agilent 6890N GC-5973N mass detector (Agilent Technologies, Massy, France). The column was an Agilent DB5-MS (30 $\mathrm{m} \times 0.25 \mathrm{~mm}$ i.d., $0.25 \mu \mathrm{m}$ film thickness) with an inlet system using the split 1:20 injection technique. Injector temperature was $250{ }^{\circ} \mathrm{C}$. Helium was used as the column carrier gas at a constant flow rate of $36 \mathrm{~cm} / \mathrm{s}$. The oven temperature was held at $70{ }^{\circ} \mathrm{C}$ for $2 \mathrm{~min}$, then raised 
to $280{ }^{\circ} \mathrm{C}$ at a rate of $10{ }^{\circ} \mathrm{C} / \mathrm{min}$ and held at $280{ }^{\circ} \mathrm{C}$ for $5 \mathrm{~min}$, then raised to $300{ }^{\circ} \mathrm{C}$ at a rate of $10^{\circ} \mathrm{C} / \mathrm{min}$ and held at $300^{\circ} \mathrm{C}$ for $5 \mathrm{~min}$. The electron impact energy was set at $70 \mathrm{eV}$; the ion source and quadrupole temperatures were 230 and $150{ }^{\circ} \mathrm{C}$, respectively. EI mass spectra ranged from 40 to $650 \mathrm{amu}$. The identification of compounds was carried out by comparing the mass spectra with those of the NIST library. The commercial standards of the targeted aromatic compounds (except vinylcatechol which was unavailable) were also analyzed using the same method.

\subsection{High Performance Liquid Chromatography (HPLC) Analysis of the Monomeric Phenolics from Fungal Culture Broth}

Daily HPLC analysis of monophenolics from the culture medium of the studied fungal species was performed at $220 \mathrm{~nm}$ and $30^{\circ} \mathrm{C}$ on a model Agilent1100 (Agilent Technologies, Massy, France) equipped with a variable UV/Vis detector and a 100-position autosampler autoinjector. Separations were achieved on a C30 reversed-phase column (YMC ${ }^{\text {TM }}$ Carotenoid $3 \mu \mathrm{m}, 4.6 \times 150 \mathrm{~mm}$, Waters, Guyancourt, France). The flow rate was $0.8 \mathrm{~mL} / \mathrm{min}$. The used mobile phases were solvent A: water acidified by $0.05 \%$ phosphoric acid and acetonitrile $(95: 5, v / v)$, and solvent B: acetonitrile $100 \%$. The gradient changed as follows: solvent B started at $10 \%$ for $4 \mathrm{~min}$, increased to $40 \%$ in $9 \mathrm{~min}$, then to $100 \%$ in $1 \mathrm{~min}$ until the end of running (18 $\mathrm{min})$. The Agilent 1100 ChemStation processed the data, and the quantification was performed by external standard calibrations.

All experiments were run in duplicate or triplicate and the standard deviation of the analyses was less than $5 \%$.

\section{Results}

\subsection{Characterization of RSM}

The moisture, fat and total phenolic contents of the RSM used in this study were of $10.0 \pm 0.1 \%$ dry matter (DM), $1.2 \pm 0.06 \% \mathrm{DM}$, and $19 \pm 1.3 \mathrm{mg} \mathrm{SAE} / \mathrm{g} \mathrm{DM}$, respectively. These data were consistent with the values available in the literature (for a review, see [1]). The sinapine and free SA content was determined after a methanolic extraction of the RSM phenolics and an alkaline hydrolysis, and was of $8 \pm 0.53 \mathrm{mg} / \mathrm{g} \mathrm{DM}(25.8 \pm 1.7 \mu \mathrm{mol} / \mathrm{g} \mathrm{DM})$ and $0.49 \pm 0.01 \mathrm{mg} / \mathrm{g} \mathrm{DM}(2.2 \pm 0.04 \mu \mathrm{mol} / \mathrm{g} \mathrm{DM})$ respectively. After alkaline hydrolysis, all the esterified forms of SA were hydrolyzed into a total of $9.77 \pm 0.27 \mathrm{mg}$ free SA/g DM $(43.6 \pm 1.2 \mu \mathrm{mol}$ free SA/g DM). The latter value represented the total amount of the potentially releasable SA per gram of meal. It was used as the $100 \%$ reference for the calculations of enzymatic hydrolysis yields.

\subsection{Release of Free SA from Meal by A. niger Esterases}

When grown in the presence of appropriate natural inducers, the strain A. niger BRFM281 has already been shown to produce feruloyl esterases able to release free hydroxycinnamic acids, including ferulic, $p$-coumaric and caffeic acids, from plant complex biomass such as cereal bran and sugar beet pulp [33]. In our study, the strain A. niger BRFM281 was grown in the presence of RSM as carbon source and enzyme inducer in the culture medium. AnFaeA, AnFaeB, and ChlE activities could be detected from day 3 to day 11 of cultivation on RSM, with maximal production of $0.67 \mathrm{nkat} / \mathrm{mL}$ AnFaeA, $0.44 \mathrm{nkat} / \mathrm{mL}$ AnFaeB and $0.29 \mathrm{nkat} / \mathrm{mL}$ ChlE on day 10, and SA was effectively released in the culture supernatant. However, SA was immediately converted into syringic acid (4-hydroxy-3,5-dimethoxybenzoic acid), certainly via a $\beta$-oxidation-type pathway as previously described for the conversion of ferulic acid into vanillic acid [34]. It is also noteworthy that no canolol could be detected in the culture medium of $A$. niger. Consequently, the release of free SA from RSM was further carried out by using the recombinant enzymes AnFaeA, AnFaeB and ChlE, formerly well-characterized in our laboratory [28-30], instead of the fungus itself.

The enzymatic hydrolysis assays were first performed by mixing $5 \mathrm{~g}$ RSM with either $30.5 \mathrm{nkat}$ AnFaeA or 18 nkat ChlE or 26.1 nkat AnFaeB at $37^{\circ} \mathrm{C}$. These activities corresponded, respectively, 
to total AnFaeA, ChlE and AnFaeB activities previously quantified in $100 \mathrm{~mL}$ of RSM-induced A. niger BRFM281 cultures, on day 4 of cultivation before any conversion of SA into syringic acid. The results of RSM hydrolysis are shown on Figure 2. It is noteworthy that RSM had been homogenized for one hour in the reaction buffer before adding the enzyme. This preliminary incubation solubilized about $50 \%$ of the amount of sinapine and $100 \%$ of the free SA initially present in the meal. AnFaeB and ChlE did not enable the release of free SA from RSM while, with AnFaeA, a total disappearance of sinapine (100\% hydrolysis) was observed after $2 \mathrm{~h}$ of incubation, correlated with a significant increase of SA in the reaction medium up to $5 \mathrm{mg} / \mathrm{g}$ DM (Figure 2). In this case, the global hydrolysis yield was about $50 \%$ (compared to the value of $9.77 \mathrm{mg} / \mathrm{g} \mathrm{DM}$ ). Then, AnFaeA was chosen for further optimization by varying the enzyme/meal ratio as well as the reaction temperature: 30.5, 131 or $196 \mathrm{nkat}$ of AnFaeA was used at 37,45 or $55^{\circ} \mathrm{C}$ (Figure 3).
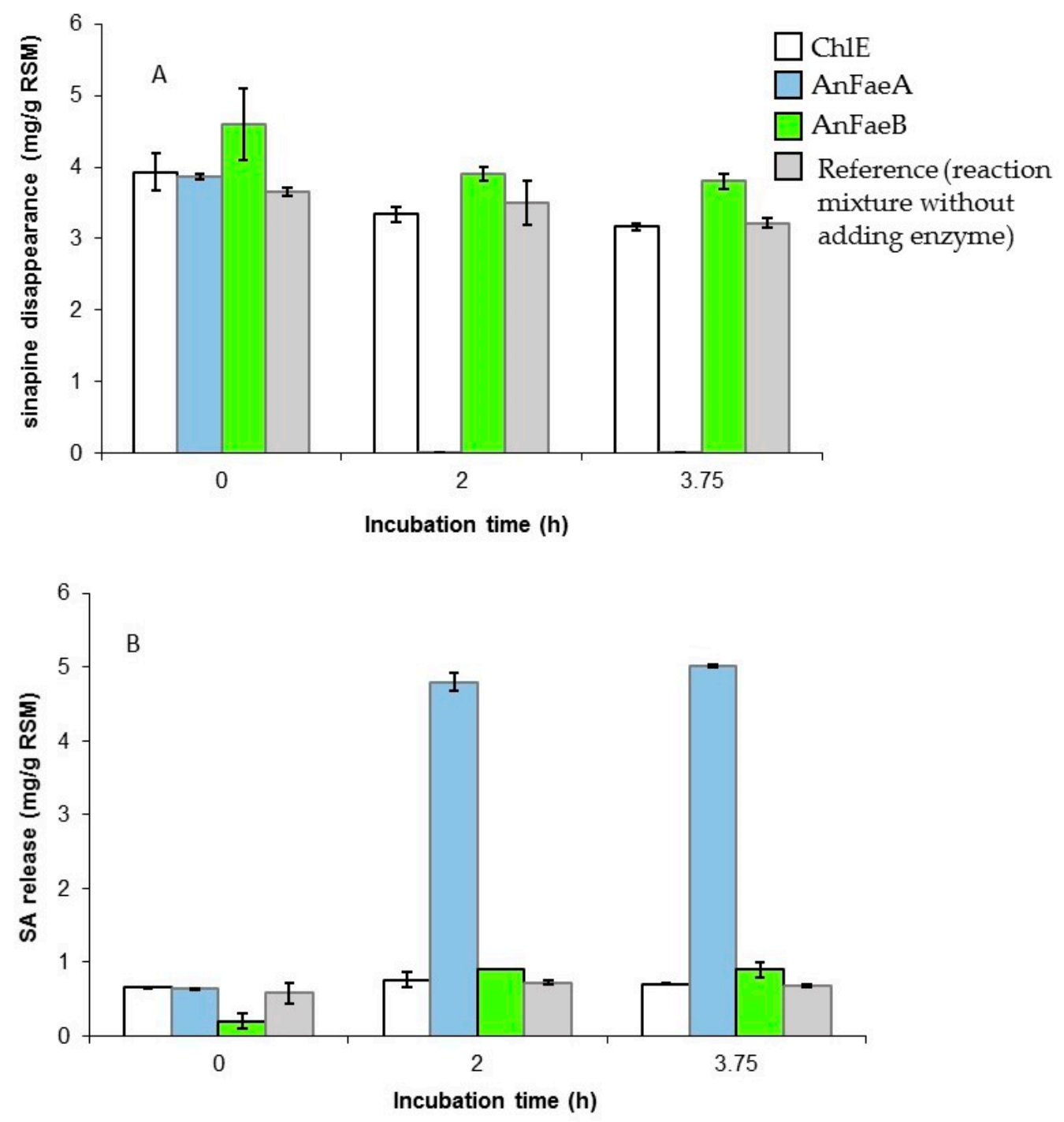

Figure 2. Time course of sinapine disappearance (A) and SA increase (B) in the reaction mixture of RSM hydrolysis as a function of the cinnamoyl esterase tested.

After $2 \mathrm{~h}$ of incubation, the results showed that, for a given amount of enzyme, the higher temperature of the reaction, the greater quantity of SA released, with an increase from 4.8 to $6.0 \mathrm{mg} / \mathrm{g}$ DM with 30.5 nkat AnFaeA, 5.7 to $7 \mathrm{mg} / \mathrm{g}$ DM with $131 \mathrm{nkat}$ AnFaeA, and 5.9 to $7.1 \mathrm{mg} / \mathrm{g}$ DM with 196 nkat AnFaeA. For a given temperature, the higher quantity of enzyme, the greater SA released, with an increase from 4.8 to $5.8 \mathrm{mg} / \mathrm{g} \mathrm{DM}$ at $37^{\circ} \mathrm{C}, 5.2$ to $6.5 \mathrm{mg} / \mathrm{g}$ DM at $45^{\circ} \mathrm{C}$, and 5.9 
to $7.1 \mathrm{mg} / \mathrm{g}$ DM at $55^{\circ} \mathrm{C}$. These results were confirmed after 3 and $4 \mathrm{~h}$ of incubation. The highest amount of free SA released $(7.4 \mathrm{mg} / \mathrm{g} \mathrm{DM})$ was obtained at $55^{\circ} \mathrm{C}$ in the presence of $196 \mathrm{nkat}$ AnFaeA after 3-4 h of incubation (Figure 3). Under these conditions, the hydrolysis yield was about $76 \%$ (compared to the value of $9.77 \mathrm{mg} / \mathrm{g}$ DM). Some other compounds, such as kaempherol derivatives, and esters of SA including di- and trisinapoyl esters were detected in the enzymatic incubation mixture (Figure S1). AnFaeA hydrolyzed not only sinapine but also glucopyranosyl sinapate, di- and trisinapoyl gentiobioside, and disinapoyl $\beta$-glucopyranoside while it did not exhibit any activity on kaempherol derivatives. The total SA, present as the free and the choline ester forms represented $28 \mu \mathrm{mol} / \mathrm{g}$ DM in the raw RSM (Table S1). After $4 \mathrm{~h}$ of AnFaeA hydrolysis, the total SA (the free form only) amount was of $29.88 \mu \mathrm{mol} / \mathrm{g}$ DM (Table S1). The molar mass balance thus showed that all the initial sinapine present in the raw RSM was enzymatically hydrolyzed in addition to some other SA esters (Figure S1) counting for about $2 \mu \mathrm{mol} \mathrm{EAS/g} \mathrm{DM.} \mathrm{Moreover,} \mathrm{the} \mathrm{analysis} \mathrm{of} \mathrm{the} \mathrm{residual}$ enzymatically-treated RSM (after 4h of AnFaeA treatment) confirmed that there was no sinapine at all in the residual meal.
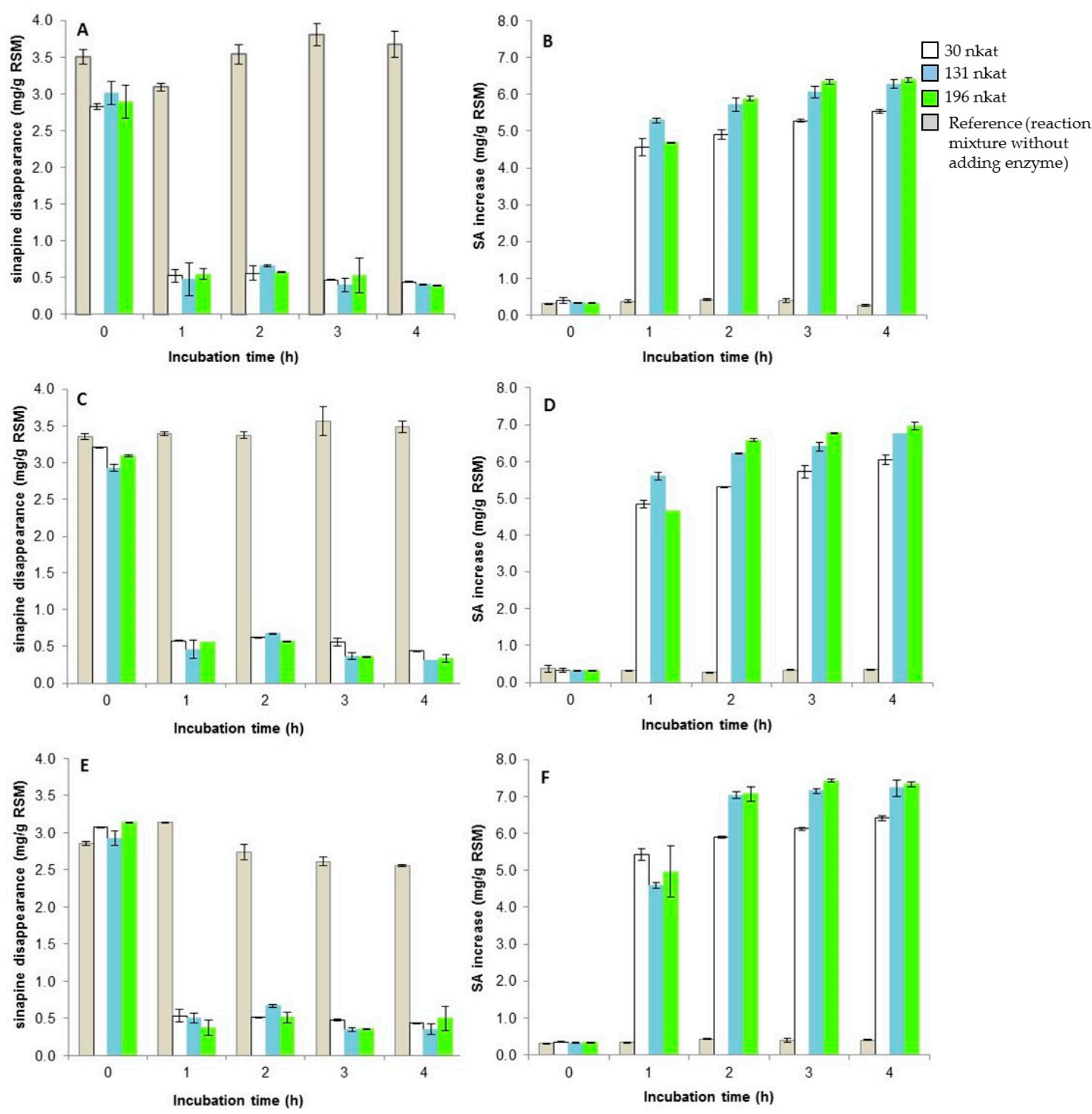

Figure 3. Time course of sinapine disappearance and SA increase in the reaction mixture of hydrolysis as a function of the amount of AnFaeA and temperature. $(\mathbf{A}, \mathbf{B}): 37^{\circ} \mathrm{C},(\mathbf{C}, \mathbf{D}): 45^{\circ} \mathrm{C},(\mathbf{E}, \mathbf{F}): 55^{\circ} \mathrm{C}$. 


\subsection{Screening of Fungal Strains able to Biotransform Hydroxycinnamic Acids into the Corresponding Vinyl Compounds}

Among the currently available and public sequenced genomes of Higher Fungi [31], few contain putative annotated PAD, including some species of Aspergillus and Penicillium for the Ascomycota phylum, and the species N. lepideus, S. commune, and S. hirsutum for the Basidiomycota phylum. The protein sequences of the fungal PADs predicted from the strains N. lepideus HHB14362, S. commune H4-8 and S. hirsutum FP-91666 from genomes [31] showed no more than 45\% similarity to known sequences of bacterial or yeast PADs. In addition, the predicted protein sequence of the N. lepideus HHB14362 PAD showed no more than 40\% similarity with those of $S$. commune and S. hirsutum (Figure S2). The strains N. lepideus BRFM15, S. commune BRFM823 and S. hirsutum BRFM889, available in the CIRM-CF collection, were thus chosen for testing their ability to biotransform either commercial SA or ferulic acid (4-hydroxy-3-methoxycinnamic acid) into canolol and 4-vinylguaiacol (2-methoxy-4-vinylphenol) respectively. Each acid was daily added from day 3 to the end of cultivation in order to maintain a final concentration of $300 \mathrm{mg} / \mathrm{L}$ in the culture medium. Sequential addition of the bioconversion precursor was performed because of the relative toxicity of phenolic compounds towards fungal growth in a general way. The results are shown on Figure $4 \mathrm{~A}-\mathrm{C}$. Only the strain N. lepideus BRFM15 was able to efficiently biotransform both SA and ferulic acid (FA) into up to $1.5 \mathrm{~g} / \mathrm{L}$ canolol and 4-vinylguaiacol (VG), respectively. The identification of canolol and VG was confirmed by GC-MS analysis (Figures S3-S6) The production of canolol from SA by N. lepideus BRFM15 started from day 4 and increased up to $1.5 \mathrm{~g} / \mathrm{L}$ on day 14 (productivity $108 \mathrm{mg} / \mathrm{L}$ day) with a molar yield of $81 \%$. About $50 \mathrm{mg} / \mathrm{L}$ syringic acid (4-hydroxy-3,5-dimethoxybenzoic acid) was concomitantly synthesized. In this case, the specific growth rate $\mu$ of $N$. lepideus BRFM15 was 0.57 day $^{-1}$. S. commune and S. hirsutum slowly consumed SA compared to N. lepideus. Traces of canolol (lower than $1 \mathrm{mg} / \mathrm{L}$ ) could be detected in the culture medium of $S$. commune grown in the presence of $S A$ whereas $S$. hirsutum did not produce any canolol. However, both strains biotransformed FA into VG. The production of VG started from day 4 of cultivation and reached $1.45 \mathrm{~g} / \mathrm{L}$ on day 14 (productivity $103 \mathrm{mg} / \mathrm{L}$ day) with a molar yield of $87 \%$ for N. lepideus BRFM15, $1.03 \mathrm{~g} / \mathrm{L}$ on day 15 (productivity $69 \mathrm{mg} / \mathrm{L}$ day) with a molar yield of $71 \%$ for S. commune BRFM823, and $69 \mathrm{mg} / \mathrm{L}$ on day 16 (productivity of $13 \mathrm{mg} / \mathrm{L}$ day) with a molar yield of $60 \%$ for S. hirsutum BRFM889. The quantity and yield of VG obtained with S. commune and $S$. hirsutum remained thus lower than those obtained with N. lepideus. The bioconversion of FA by S. commune and S. hirsutum led also to the synthesis of vanillic acid (4-hydroxy-3-methoxybenzoic acid) in amounts lower than $90 \mathrm{mg} / \mathrm{L}$. The strain N. lepideus BRFM15 was selected for subsequent studies of SA bioconversion into canolol.

\subsection{Selection of a Specific Adsorbent for SA or Canolol Recovery}

The use of a specific adsorbent should independently permit: (i) the recovery and concentration of SA, released from RSM after AnFaeA hydrolysis and further used as bioconversion precursor for feeding N. lepideus cultures; (ii) the recovery of canolol from the culture broth of N. lepideus BRFM 15 after bioconversion of SA.

In the first case, the choice of the most suitable adsorbent was thus determined by assessing the ability to adsorb a maximum of SA. Since the $\mathrm{pK}_{\mathrm{A} 1}$ and $\mathrm{pK}_{\mathrm{A} 2}$ of $\mathrm{SA}$ were 4.6 and 9.95 respectively, the hydrophobic resins were tested at $\mathrm{pH} 4$ where SA was totally in the protonated form. In the second case, the selected adsorbent should trap high amounts of canolol and show the lower affinity for SA. The adsorption ratios of four resins, XAD1180, XAD16, XAD2, and SP207, for SA or canolol, are shown in Table 1. At $\mathrm{pH} 4$, all the resins showed high affinity for SA. At $\mathrm{pH} 7$, the most selective adsorbent was XAD2 with which $97 \%$ of the total canolol was recovered against only about $31 \%$ of SA. The XAD2 resin thus showed the best compromise for the use in both steps of the process.

A subsequent assay of canolol batch production and recovery was performed with a 4.5-L culture of N. lepideus BRFM15 supplemented with commercial SA. After 13 days of cultivation where the concentration of SA was maintained daily at $300 \mathrm{mg} / \mathrm{L}$ in the medium, the supernatant $(4.2 \mathrm{~L})$ contained 
$1.74 \mathrm{~g}$ residual SA and $4.54 \mathrm{~g}$ canolol. After separation from the mycelium, it was then adjusted to $\mathrm{pH}$ 7, added to $420 \mathrm{~g}$ XAD2 resin, and incubated overnight at $30^{\circ} \mathrm{C}$ and $120 \mathrm{rpm}$. Then, the compounds were eluted from XAD2 with methanol. HPLC analysis of the resulting methanolic solution showed that it contained only canolol and SA, with quantities of $3.7 \mathrm{~g}$ canolol $(82.5 \%)$ and $0.787 \mathrm{~g} \mathrm{SA}(17.5 \%)$.

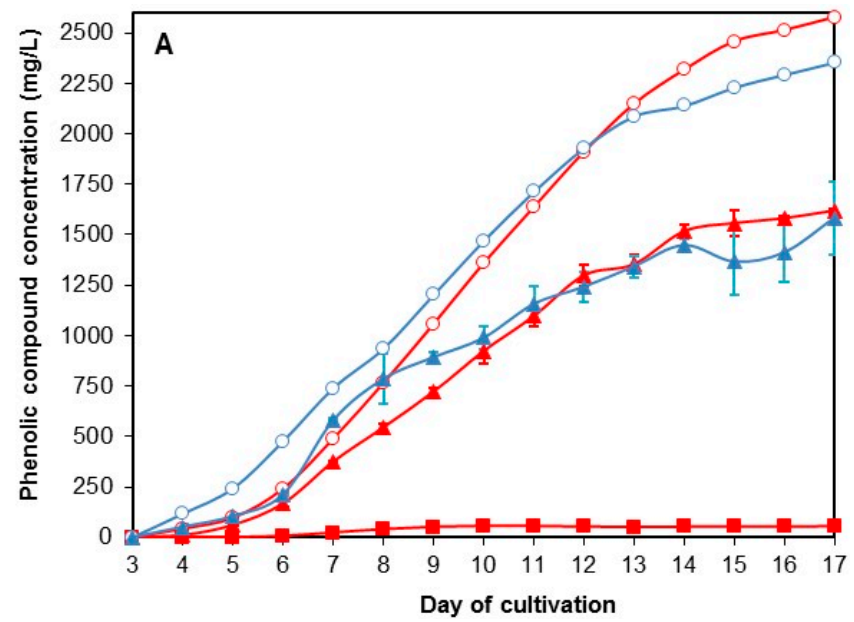

O consumed SA

O consumed FA

$\Delta$ canolol

syringic acid

A 4-vinylguaiacol

vanillic acid

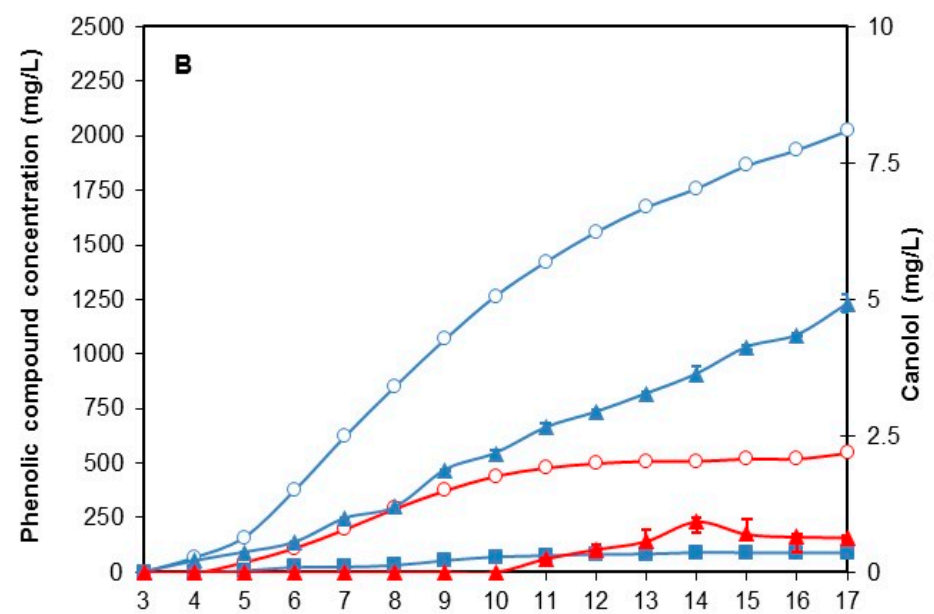

Day of cultivation

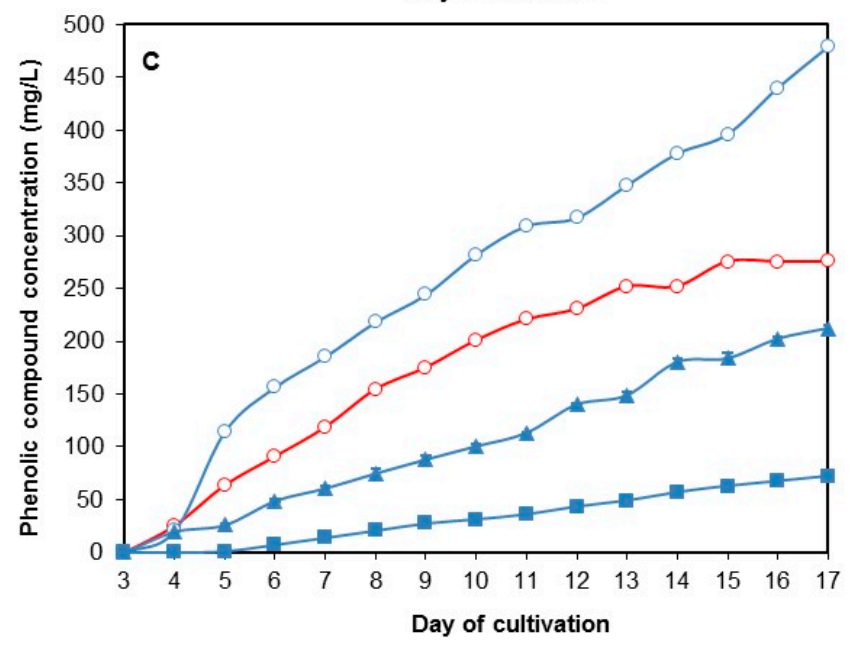

Figure 4. SA and FA metabolism by N. lepideus BRFM 15 (A), S. commune BRFM823 (B) and S. hirsutum BRFM889 (C): consumption of SA or FA in relation to the production of canolol and syringic acid, and VG and vanillic acid, respectively. 
Table 1. Adsorption of SA and canolol for the different resins tested.

\begin{tabular}{ccccc}
\hline \multicolumn{5}{c}{ Adsorption Ratio ${ }^{\text {a }} \mathbf{( \% )}$} \\
\hline pH 4 & pH 7 \\
\hline Type of adsorbent & SA & canolol & SA & canolol \\
XAD1180 & $94.2 \pm 0.1$ & $98.1 \pm 0$ & $37.7 \pm 0.3$ & $98.1 \pm 0$ \\
XAD16 & $98.8 \pm 0$ & $99.1 \pm 0$ & $56.3 \pm 1.0$ & $99.2 \pm 0$ \\
XAD2 & $84.9 \pm 0.1$ & $96.9 \pm 0.2$ & $30.8 \pm 0.2$ & $97.3 \pm 0$ \\
SP207 & $99.3 \pm 0$ & $100 \pm 0$ & $75.2 \pm 1.0$ & $100 \pm 0$ \\
\hline \multicolumn{5}{c}{ a Values are given as the mean \pm standard deviation $(n=2)}$.
\end{tabular}

\subsection{The Two-Step Bioconversion Process: Batch Production of Natural SA from Rapeseed Meal and} Bioconversion into Canolol

In a first step, $410 \mathrm{~g}$ (dry matter) of RSM was incubated with 17,640 nkat of AnFaeA (i.e., 39 nkat AnFaeA per gram of meal) in $8 \mathrm{~L}$ of $100 \mathrm{mM}$ MOPS buffer $(\mathrm{pH} 5)$, at $55^{\circ} \mathrm{C}$ for $3.5 \mathrm{~h}$ with an agitation of $500 \mathrm{rpm}$. At the end of the incubation period, $2.71 \mathrm{~g} \mathrm{SA}$ was released which corresponded to a total hydrolysis of sinapine and a global hydrolysis yield of $68 \%$. After separation from the residual meal, the enzymatic hydrolysis supernatant, which $\mathrm{pH}$ was adjusted to 4 , was then incubated overnight at $30{ }^{\circ} \mathrm{C}$ with $500 \mathrm{~g}$ XAD2 resin with orbital stirring of $160 \mathrm{rpm}$. The elution of bound SA was carried out with ethanol, and resulted in the recovery of $2.46 \mathrm{~g} \mathrm{SA}$, which corresponded to $91 \%$ of the amount of the SA released from the raw meal. Ethanol was then evaporated under low pressure at $30^{\circ} \mathrm{C}$, in order to obtain an ethanolic solution of natural SA with a concentration of $25 \mathrm{~g} / \mathrm{L}$.

In a second step, the natural SA ethanolic solution was subsequently added to 3-day-old cultures of N. lepideus BRFM15 and then fed daily to maintain a final concentration of $300-400 \mathrm{mg} / \mathrm{L}$ in the culture medium. The results were compared to the equivalent bioconversion process performed with commercial SA added as either an ethanolic or an aqueous solution (Figure 5). The production of canolol from natural SA started on day 4 of cultivation to reach the maximum concentration of $1.277 \mathrm{~g} / \mathrm{L}$ on day 13 with a productivity of $100 \mathrm{mg} / \mathrm{L}$ day and a molar yield of $80 \%$. It is noteworthy that the supply of either natural or commercial SA as an ethanolic solution made it possible the decrease of syringic acid synthesis by a factor of 1.6-2, during the first 9 days of cultivation, compared with commercial SA dissolved in water.

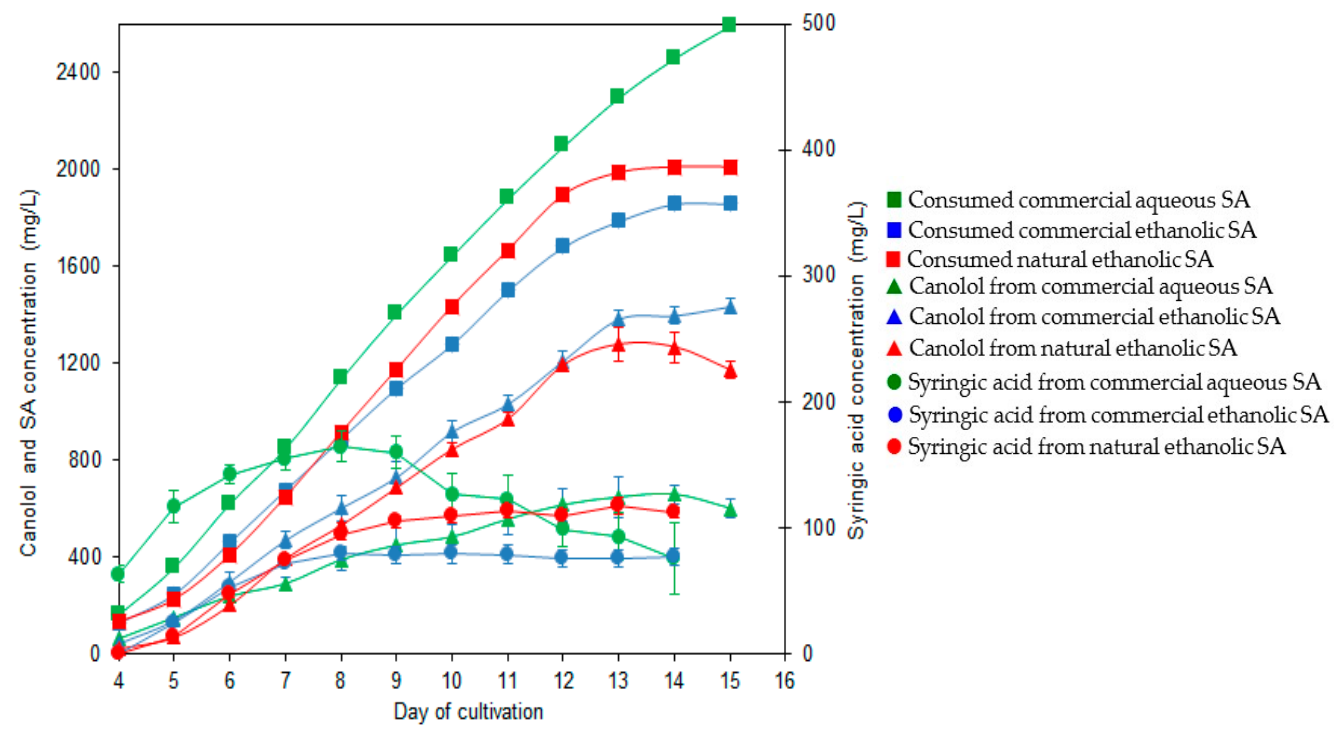

Figure 5. Comparison of SA metabolism by N. lepideus BRFM15 supplemented with different sources of SA. Cultivations were carried out in the presence of aqueous commercial SA (green symbols), ethanolic commercial SA (blue symbols), and natural ethanolic SA from RSM (red symbols). Consumption of SA in relation to the production of canolol and syringic acid. 


\section{Discussion}

RSM is a cheap (250-350 $€$ /ton in Europe) and abundant raw material. Europe is the world's largest producer of RSM ahead of China, Canada and India [2]. Given that the annual European production of RSM is about 13 million tons a year and that RSM content in SA is about $1 \%$ DM, there are about 130,000 tons of SA annually available. Canolol is a derivative of SA with numerous applications in pharmaceutical, cosmetic and food industries because of its high antioxidant, anti-mutagenic and anticarcinogenic properties. In this work, a two-step bioconversion process of natural SA from RSM to canolol was elaborated combining the complementary potentialities of two filamentous fungi, the micromycete $A$. niger and the basidiomycete $N$. lepideus. In the first step, the AnFaeA recombinant enzyme from $A$. niger permitted the hydrolysis of the esterified forms of SA in meal (mainly sinapine and and glucopyranosyl sinapate) and its release in the free form. In the second step, free SA was non-oxidatively decarboxylated into canolol by N. lepideus.

Obtaining free SA from RSM can be carried out by alkaline hydrolysis and methanol extraction [22,35], but in harsh conditions (high temperature, strong base and toxic solvent), which could be incompatible with a green process. The use of commercial esterase preparations for SA extraction from meal has already been carried out but for analytical purposes only till now [35]. In our work, we exploited the ability of the species A. niger to synthesize a large panel of feruloyl and other cinnamoyl esterases when grown on agro-industrial by-products [33]. The strain A. niger BRFM281 has already been successfully used in a patented two-step process enabling the synthesis of vanillin from FA of maize bran. In the first step, A. niger released free FA from maize bran. In the second step, the bioconversion of free FA to vanillin was carried out by the food-grade basidiomycete Pycnoporus cinnabarinus [36]. In our case, a limiting step in the use of the fungus $A$. niger, when grown on RSM, was the degradation of the SA propenoic chain into syringic acid. The bottleneck was overcome by the use of the recombinant enzyme AnFaeA instead of the fungus. The recombinant A. niger AnFaeA used in this study was already characterized and produced, in our laboratory, at yields up to $1 \mathrm{~g} / \mathrm{L}$ [28]. Feruloyl and cinnamoyl esterases (carboxyl ester hydrolases, EC 3.1.1), found especially in the genus Aspergillus, have been described as enzymes hydrolyzing ester linkages between hydroxycinnamic acid and sugars present in the plant cell wall [37]. In vivo, they have complex substrate specificities depending on the substituent present on the aromatic ring and the type of sugar bonding. For instance, type- $\mathrm{A}$ feruloyl esterases, such as AnFaeA, are active on the methyl esters of the highly substituted ferulic and sinapic acids, and on natural 1,5-esterified feruloylated oligomers from cereals, whereas type-B feruloyl esterases, such as AnFaeB, are active on the methyl esters of the hydroxylated cinnamic acids caffeic and $p$-coumaric acids, and on natural 1,2- and 1,6-esterified feruloylated oligomers from sugar beet pulp $[38,39]$. Pure AnFae were described as essentially inactive when used directly on the raw material [40]. In our case, we showed that (i) AnFaeA, AnFaeB and ChlE were induced in cultures of $A$. niger grown on RSM; and (ii) that pure AnFaeA could effectively hydrolyze sinapine (a choline ester of SA) from the meal. Moreover, the use of 39 nkat AnFaeA per gram RSM, at $55^{\circ} \mathrm{C}$ and $\mathrm{pH} 5$, permitted the total hydrolysis of sinapine and the recovery of free SA with a global yield of $68-76 \%$.

$N$. lepideus is a basidiomycete of the Polyporaceae family and is currently one of the most consumed edible mushroom in Asia as well as the common mushroom Agaricus bisporus in Europe and North America. It was first described for its special ability to $O$-methylate or methoxylate $p$-cinnamic acids and to produce sweet flavors including $p$-methoxycinnamate, methyl cinnamate and methyl $p$-methoxycinnamate [41]. N. lepideus was also well-known as the agent responsible for the decay of railway sleepers and telegraph poles treated with creosote, a wood preservative, against which it showed an outstanding tolerance. More recently, N. lepideus was shown to produce biologically active compounds, e.g., the glycoprotein lepidane or soluble polysaccharides, with immunomodulating activities [42,43]. Extracts from carpophores of $N$. lepideus also possessed anti-radical and antioxidant activities [44]. Otherwise, N. lepideus demonstrated the particularity, rather exceptional in a basidiomycete, of assimilating and fermenting the pentose xylose from lignocellulosic biomasses to convert it into ethanol (a still limiting step in the synthesis of bioethanol 2G) with a yield 
of $0.3 \mathrm{~g} / \mathrm{g}$ [45]. The species N. lepideus is thus of biotechnological interest. In our study, N. lepideus BRFM15 was the only fungus able to biotransform both free FA and SA to VG (a flavoring agent and a precursor of biopolymers of industrial interest) and canolol respectively, with concentrations up to $1.5 \mathrm{~g} / \mathrm{L}$. Interestingly, this suggested that $\mathrm{N}$. lepideus did possess a PAD with very good affinity for both SA and FA. In addition, N. lepideus BRFM15 was also able to biotransform free $p$-coumaric acid and caffeic acid into 4-vinylphenol and 4-vinylcatechol respectively; however, it was unable to perform the bioconversion directly from raw natural materials (data not shown). GC-MS analysis of N. lepideus culture broth from SA to canolol bioconversion highlighted the presence of small traces of syringic acid, syringaldehyde and syringyl alcohol. In N. lepideus BRFM15 culture broth from FA to VG, were also detected as traces by GC-MS: vanillic acid, vanillin, vanillyl alcohol, syringic acid, syringaldehyde, syringyl alcohol, protocatechuic acid and derivatives of $p$-methoxycinnamate. In the light of the present work and reports on fungal aromatic metabolisms in the literature [46-48], it seemed that, for N. lepideus, the route of SA and FA biotransformation into the corresponding vinyl derivatives was highly favored compared to the others pathways. Especially, the bioconversion of hydroxycinnamic acids into the benzoic acid derivatives, via a $\beta$-oxidation-like reaction, is a minor pathway in $N$. lepideus BRFM15 unlike other Polyporaceae known for their aromatic flavor metabolism, including P. cinnabarinus [46] and Trametes suaveolens [47]. In our process, the concentrations of canolol obtained were up to $1.5 \mathrm{~g} / \mathrm{L}$. Among filamentous fungi, the synthesis of $0.75-1.15 \mathrm{mg} / \mathrm{L}$ canolol from $200 \mathrm{mg} / \mathrm{L}$ SA (potentially from olive mill wastewaters) has been recently described in Phomopsis liquidambari, a phytopathogenous ascomycete [48]. According to our batch assay, the global yield of the process was $3.3 \mathrm{mg}$ canolol per gram of RSM, which was similar to the value obtained with the crude Bacillus subtilis PAD-process in water-toluene system [11]. In both cases, biotechnological treatments led to a 4.1 to 6.6-fold increase in canolol synthesis per gram of RSM, compared to heat treatments [20-22]. The use of specific adsorbents to trap aromatic compounds in culture broths has already been shown to be a safe and easy-to-handle method $[49,50]$. In our case, the same XAD2 resin could be used with high efficiency for both steps of the process, which constitutes an advantage for industrial scaling-up. To the best of our knowledge, this is the first report on a fungal/enzymatic bioconversion process of natural SA from RSM into canolol, compatible with sustainable biotechnological applications.

This work opens up new perspectives on the study and biotechnological use of fungal PADs. Indeed, these intracellular enzymes (generally homodimeric) responsible for the microbial non-oxidative decarboxylation of hydroxycinnamic acids have never been purified and characterized to our knowledge in filamentous fungi. Moreover, the substrate specificity of the native bacterial and yeast PADs was described mainly for ferulic, $p$-coumaric (pCA) and caffeic (CafA) acids, in the decreasing order [51,52]. Recently, a PAD from Bacillus licheniformis was shown to possess a broader substrate activity including pCA, FA, CafA, and SA decarboxylation but with the relative ratios of specific activities 100:75.6:34.4:0.3, respectively [53]. Obviously, cloning the N. lepideus PAD gene would enable to better understand the functioning, the specificity towards SA and the phylogeny of this enzyme.

Supplementary Materials: Supplementary materials can be found at www.mdpi.com/2076-2607/5/4/67/s1.

Acknowledgments: This work was funded by the Technical Centre for Oilseed Crops, Grain Legumes and Industrial Hemp (TERRES INOVIA, Pessac, France) and the Inter-Branch Organization for Vegetable Oils and Proteins (TERRES UNIVIA, Paris, France). The authors warmly thank Jean-Luc Cayol (Aix-Marseille University, France), Canelle Laugeois, Alexandre Bona and David Cave (Polytech Marseille, France) for participation and helpful comments on the manuscript, and Lucile Sage from University Joseph Fourier (Grenoble, France) for the deposit of the strain Schizophyllum commune CMPG1552 in the International Centre of Microbial Resources, as strain BRFM823.

Author Contributions: Anne Lomascolo conceived, designed, supervised the experiments, and wrote the paper. Elise Odinot performed the experiments, with the support of Alexandra Bisotto and David Navarro. Christian Ginies, Oscar Laguna and Jérôme Lecomte contributed to GC-MS and HPLC measurements. Frédéric Fine, Jean-Claude Sigoillot, Corinne Peyronnet and Craig B. Faulds contributed to the conception of the work and help to write the first draft of the paper. All the authors contributed to finalizing the manuscript.

Conflicts of Interest: The authors declare no conflict of interest. 


\section{References}

1. Lomascolo, A.; Uzan-Boukris, E.; Sigoillot, J.-C.; Fine, F. Rapeseed and sunflower meal: A review on biotechnology status and challenge. Appl. Microbiol. Biotechnol. 2012, 95, 1105-1114. [CrossRef] [PubMed]

2. Agricultural Production Statistics by Country-IndexMundi. Available online: http://www.indexmundi. com/agriculture (accessed on 5 February 2017).

3. Briones, R.; Serrano, L.; Labidi, J. Valorisation of some lignocellulosic agro-industrial residues to obtain biopolyols. J. Chem. Technol. Biotechnol. 2011, 87, 244-249. [CrossRef]

4. Yeoman, K.H.; Edwards, C. Protease production by Streptomyces thermovulgaris grown on rapemeal-derived media. J. Appl. Bacteriol. 1994, 77, 264-270. [CrossRef] [PubMed]

5. Rajoka, M.I.; Huma, T.; Khalid, A.M.; Latif, F. Kinetics of enhanced substrate consumption and endo- $\beta$-xylanase production by a mutant derivative of Humicola lanuginosa in solid-state fermentation. World J. Microbiol. Biotechnol. 2005, 21, 869-876. [CrossRef]

6. Zabaniotou, A.; Ioannidou, O.; Skoulou, V. Rapeseed residues utilization for energy and 2nd generation biofuels. Fuel 2008, 87, 1492-1502. [CrossRef]

7. Wang, R.; Shaarani, S.M.; Godoy, L.C.; Melikoglu, M.; Vergara, C.S.; Koutinas, A.; Webb, C. Bioconversion of rapeseed meal for the production of a generic microbial feedstock. Enzym. Microb. Technol. 2010, 47, 77-83. [CrossRef]

8. Chen, K.; Zhang, H.; Miao, Y.; Wei, P.; Chen, J. Simultaneous saccharification and fermentation of acid-pretreated rapeseed meal for succinic acid production using Actinobacillus succinogenes. Enzym. Microb. Technol. 2011, 48, 339-344. [CrossRef] [PubMed]

9. Yao, D.; Ji, Z.; Wang, C.; Qi, G.; Zhang, L.; Ma, X.; Chen, S. Co-producing iturin A and poly- $\gamma$-glutamic acid from rapeseed meal under solid state fermentation by the newly isolated Bacillus subtilis strain 3-10. World J. Microbiol. Biotechnol. 2012, 28, 985-991. [CrossRef] [PubMed]

10. Vuorela, S.; Meyer, A.; Heinonen, M. Impact of isolation method on the antioxidant activity of rapeseed meal phenolics. J. Agric. Food Chem. 2004, 52, 8202-8207. [CrossRef] [PubMed]

11. Morley, K.L.; Grosse, S.; Leisch, H.; Lau, P.C.K. Antioxidant canolol production from a renewable feedstock via an engineered decarboxylase. Green Chem. 2013, 15, 3312-3317. [CrossRef]

12. Koski, A.; Pekkarinen, S.; Hopia, A.; Wähälä, K.; Heinonen, M. Processing of rapeseed oil: Effects on sinapic acid derivative content and oxidative stability. Eur. Food Res. Technol. 2003, 217, 110-114. [CrossRef]

13. Wakamatsu, D.; Morimura, S.; Sawa, T.; Kida, K.; Nakai, C.; Maeda, H. Isolation, identification, and structure of a potent alkyl-peroxyl radical scavenger in crude canola oil, canolol. Biosci. Biotechnol. Biochem. 2005, 69, 1568-1574. [CrossRef] [PubMed]

14. Kuwahara, H.; Kanazawa, A.; Wakamatu, D.; Morimura, S.; Kida, K.; Akaike, T.; Maeda, H. Antioxidative and antimutagenic activities of 4-vinyl-2,6-dimethoxyphenol (canolol) isolated from canola oil. J. Agric. Food Chem. 2004, 52, 4380-4387. [CrossRef] [PubMed]

15. Dong, X.; Li, Z.; Wang, W.; Zhang, W.; Liu, S.; Zhang, X.; Fang, J.; Maeda, H.; Matsukura, M. Protective effect of canolol from oxidative stress-induced cell damage in ARPE-19 via an ERK mediated antioxidative pathway. Mol. Vision 2011, 17, 2040-2048.

16. Cao, X.; Tsukamoto, T.; Seki, T.; Tanaka, H.; Morimura, S.; Cao, L.; Mizoshita, T.; Ban, H.; Toyoda, T.; Maeda, H.; Tatematsu, M. 4-Vinyl-2,6-dimethoxyphenol (canolol) suppresses oxidative stress and gastric carcinogenesis in Helicobacter pylori-infected carcinogen-treated Mongolian gerbils. Int. J. Cancer 2008, 122, 1445-1454. [CrossRef] [PubMed]

17. Maeda, H.; Kumamoto, J.P.; Tsukamoto, T.; Tatematsu, M.; Nagoya-shi, J.P. Anti-Inflammatory Agent and Cancer-Preventive Agent Comprising Canolol or Prodrug Thereof and Pharmaceutical, Cosmetic and Food Comprising the Same. U.S. Patent 2012/0122995 A1, 2012.

18. Aouf, C.; Zago, E.; Lecomte, J.; Villeneuve, P.; Fulcrand, H.; Fine, F.; Rous, J.-F. Polyaromatic Dimers, Method for Preparing Same and Use of Same. Patent WO2016/097657, 1 September 2016.

19. Zago, E.; Dubreucq, E.; Lecomte, J.; Villeneuve, P.; Fine, F.; Fulcrand, H.; Aouf, C. Synthesis of bio-based epoxy monomers from natural ally- and vinyl phenols and the estimation of their affinity to the oestrogen receptot $\alpha$ by molecular docking. New J. Chem. 2016, 40, 7701-7710. [CrossRef] 
20. Pudel, F.; Habicht, V.; Piofczyk, T.; Matthäus, B.; Quirin, K.W.; Cawelius, A. Fluidized bed treatment of rapeseed meal and cake as possibility for the production of canolol. Oilseeds Fats Crop. Lipids 2014, 21, D103. [CrossRef]

21. Yang, M.; Zheng, C.; Zhou, Q.; Liu, C.; Li, W.; Huang, F. Influence of microwaves treatment of rapeseed on phenolic compounds and canolol content. J. Agric. Food. Chem. 2014, 62, 1956-1963. [CrossRef] [PubMed]

22. Zago, E.; Lecomte, J.; Barouh, N.; Aouf, C.; Carré, P.; Fine, F.; Villeneuve, P. Influence of rapeseed meal treatments on its total phenolic content and composition in sinapine, sinapic acid and canolol. Ind. Crop. Prod. 2015, 76, 1061-1070. [CrossRef]

23. Li, J.; Guo, Z. Concurrent extraction and transformation of bioactive phenolic compounds from rapeseed meal using pressurized solvent extraction system. Ind. Crop. Prod. 2016, 94, 152-159. [CrossRef]

24. Steinke, R.D.; Paulson, M.C. The production of steam-volatile phenols during the cooking and alcoholic fermentation of grain. J. Agric. Food Chem. 1964, 12, 381-387. [CrossRef]

25. Godoy, L.; Martinez, C.; Carrasco, N.; Ganga, M.A. Purification and characterization of $p$-coumarate decarboxylase and a vinylphenol reductase from Brettanomyces bruxellensis. Int. J. Food Microbiol. 2008, 127, 6-11. [CrossRef] [PubMed]

26. Matte, A.; Grosse, F.; Bergeron, H.; Abokitse, K.; Lau, P.C.K. Structural analysis of Bacillus pumilus acid decarboxylase, a lipocalin-fold enzyme. Acta Crystallogr. Sect. F Struct. Biol. Cryst. Commun. 2010, 66, 1407-1414. [CrossRef] [PubMed]

27. Huang, H.-K.; Tokashiki, M.; Maeno, S.; Onaga, S.; Taira, T.; Ito, S. Purification and properties of phenolic acid decarboxylase from Candida guilliermondii. J. Ind. Microbiol. Biotechnol. 2012, 39, 55-62. [CrossRef] [PubMed]

28. Record, E.; Asther, Mi.; Sigoillot, C.; Pages, S.; Punt, P.J.; Delattre, M.; Haon, M.; Van den Hondel, C.A.; Sigoillot, J.-C.; Lesage-Meessen, L.; Asther, M. Overproduction of Aspergillus niger feruloyl esterase for pulp bleaching application. Appl. Microbiol. Biotechnol. 2003, 62, 349-355. [CrossRef] [PubMed]

29. Levasseur, A.; Benoit, I.; Asther, Mi.; Asther, M.; Record, E. Homologous expression of the feruloyl esterase B gene from Aspergillus niger and characterization of the recombinant enzyme. Protein Expr. Purif. 2004, 37, 126-133. [CrossRef] [PubMed]

30. Benoit, I.; Asther, Mi.; Bourne, Y.; Navarro, D.; Canaan, S.; Lesage-Meessen, L.; Herweijer, M.; Coutinho, P.M.; Asther, M.; Record, E. Gene overexpression and biochemical characterization of the biotechnologically relevant chlorogenic acid hydrolase from Aspergillus niger. Appl. Environ. Microbiol. 2007, 73, 5624-5632. [CrossRef] [PubMed]

31. National Center for Biotechnology Information. Available online: https://www.ncbi.nlm.nih.gov/protein/ (accessed on 1 July 2017).

32. Ralet, M.-C.; Faulds, C.B.; Williamson, G.; Thibaut, J.-F. Degradation of feruloylated oligosaccharides from sugar-beet pulp and wheat bran by ferulic acid esterases from Aspergillus niger. Carbohydr. Res. 1994, 263, 257-269. [CrossRef]

33. Bonnin, E.; Brunel, M.; Gouy, Y.; Lesage-Meessen, L.; Asther, M.; Thibault, J.-F. Aspergillus niger I-1472 and Pycnoporus cinnabarinus MUCL39533, selected for the biotransformation of ferulic acid to vanillin, are also able to produce cell wall polysaccharide-degrading enzymes and feruloyl esterases. Enzym. Microb. Technol. 2001, 28, 70-80. [CrossRef]

34. Falconnier, B.; Lapierre, C.; Lesage-Meesen, L.; Yonnet, G.; Brunerie, P.; Colonna-Ceccaldi, B.; Corrieu, G.; Asther, M. Vanillin as a product of ferulic acid biotransformation by the white-rot fungus Pyncoporus cinnabarinus I-937: Identification of metabolic pathways. J. Biotechnol. 1994, 37, 123-132. [CrossRef]

35. Vuorela, S.; Meyer, A.; Heinonen, M. Quantitative analysis of the main phenolics in rapeseed meal and oils processed differently using enzymatic hydrolysis and HPLC. Eur. Food Res. Technol. 2003, 217, 517-523. [CrossRef]

36. Lesage-Meessen, L.; Lomascolo, A.; Bonnin, E.; Thibault, J.-F.; Buleon, A.; Roller, M.; Asther, M.; Record, E.; Colonna Ceccaldi, B.; Asther, M. A biotechnological process involving filamentous fungi to produce natural crystalline vanillin from maize bran. Appl. Biochem. Biotechnol. 2002, 102-103, 141-153. [CrossRef]

37. Faulds, C.B. What can feruloyl esterases do for us? Phytochem. Rev. 2010, 9, 121-132. [CrossRef]

38. Faulds, C.B.; Williamson, G. Purification and characterization of a ferulic acid esterase (FAE-III) from Aspergillus niger: Specificity for the phenolic moiety and binding to microcrystalline cellulose. Microbiology 1994, 140, 779-787. [CrossRef] 
39. Brezillon, C.; Kroon, P.A.; Faulds, C.B.; Brett, G.M.; Williamson, G. Novel ferulic acid esterases are induced by growth of Aspergillus niger on sugar beet pulp. Appl. Microbiol. Biotechnol. 1996, 45, 371-376. [CrossRef]

40. Bonnin, E.; Lesage-Meessen, L.; Asther, M.; Thibault, J.-F. A new process using Aspergillus niger and its enzymes for the production of vanillin and related compounds from agro-industrial by-products. Afinidad LVII 2000, 489, 357-364.

41. Shimazono, H. Investigations on lignins and lignification. Identification of a phenolic ester in the culture medium of Lentinus lepideus and the $O$-methylation of methyl $p$-coumarate to methyl $p$-methoxycinnamate in vivo. Arch. Biochem. Biophys. 1959, 83, 206-215. [CrossRef]

42. Jin, M.; Kim, S.; Kim, B. Induction of B-cell proliferation and NF-B activation by water-soluble glycan from Neolentinus lepideus. Int. J. Immunopharmacol. 1996, 18, 439-448. [CrossRef]

43. Jin, M.; Jeon, H.; Jung, J.-H.; Kim, C.; Shin, S.; Choi, J.; Lee, K.; Kang, Y.; Kim, Y. Activation of selective transcription factor and cytokines by a water-soluble exctract from Neolentinus lepideus. Exp. Biol. Med. 2003, 228, 749-758. [CrossRef]

44. Yoon, K.N.; Alam, N.; Lee, K.R.; Shin, P.G.; Cheong, J.C.; Yoo, Y.B.; Lee, T.S. Antioxidant and antityrosinase activities of various extracts from the fruiting bodies of Lentinus lepideus. Molecules 2011, 16, $2334-2347$. [CrossRef] [PubMed]

45. Okamoto, K.; Kanawaku, R.; Masumoto, M.; Yanase, H. Efficient xylose fermentation by the brown rot fungus Neolentinus lepideus. Enzym. Microb. Technol. 2012, 50, 96-100. [CrossRef] [PubMed]

46. Krings, U.; Pilawa, S.; Theobald, C.; Berger, R.G. Phenyl propenoic side chain degradation of ferulic acid by Pycnoporus cinnabarinus_Elucidation of metabolic pathways using [5-2 $\mathrm{H}]$-ferulic acid. J. Biotechnol. 2001, 85, 305-314. [CrossRef]

47. Lomascolo, A.; Asther, M.; Navarro, D.; Antona, C.; Delattre, M.; Lesage-Meessen, L. Shifting the biotransformation pathways of L-phenylalanine into benzaldehyde by Trametes suaveolens CBS334.85 using HP20 resin. Lett. Appl. Microbiol. 2001, 32, 262-267. [CrossRef] [PubMed]

48. Xie, X.G.; Huang, C.Y.; Fu, W.Q.; Dai, C.C. Potential of endophytic fungus Phomopsis liquidambari for transformation and degradation of recalcitrant pollutant sinapic acid. Fungal Biol. 2016, 120, 402-413. [CrossRef] [PubMed]

49. Xue, Y.P.; Liu, Z.Q.; Xu, M.; Wanga, Y.J.; Zhenga, Y.G.; Shen, Y.C. Enhanced biotransformation of $(R, S)$-mandelonitrile to $(R)-(-)$-mandelic acid with in situ production removal by addition of resin. Biochem. Eng. J. 2010, 53, 143-149. [CrossRef]

50. Wang, P.; He, J.Y.; Yin, J.F. Enhanced biocatalytic production of L-cysteine by Pseudomonas sp. B-3 with in situ product removal using ion-exchange resin. Bioprocess Biosyst. Eng. 2015, 38, 421-428. [CrossRef] [PubMed]

51. Cavin, J.F.; Dartois, V.; Divies, C. Gene cloning, transcriptional analysis, purification, and characterization of phenolic acid decarboxylase from Bacillus subtilis. Appl. Environ. Microbiol. 1998, 64, 1466-1471. [PubMed]

52. Landete, J.M.; Rodríguez, H.; Curiel, J.A.; de las Rivas, B.; Mancheño, J.M.; Muñoz, R. Gene cloning, expression, and characterization of phenolic acid decarboxylase from Lactobacillus brevis RM84. J. Ind. Microbiol. Biotechnol. 2012, 37, 617-624. [CrossRef] [PubMed]

53. Hu, H.; Li, L.; Ding, S. An organic solvent-tolerant phenolic acid decarboxylase from Bacillus licheniformis for the efficient bioconversion of hydroxycinnamic acids to vinyl phenol derivatives. Appl. Microbiol. Biotechnol. 2015, 99, 5071-5081. [CrossRef] [PubMed]

(C) 2017 by the authors. Licensee MDPI, Basel, Switzerland. This article is an open access article distributed under the terms and conditions of the Creative Commons Attribution (CC BY) license (http://creativecommons.org/licenses/by/4.0/). 